\title{
Effect of Mn Doping on The Structural, Optical, Magnetic Properties and Antibacterial Activity of ZnO Nanospheres
}

EBENEZAR JEYASINGH ( $\sim$ ebey_ebenezar@yahoo.com )

Jamal Mohamed College https://orcid.org/0000-0001-7391-5429

Kelvin Adaikalam Charles

Jamal Mohamed College

Pandiyarajan Thangaraj

Indian Institute of Information Technology Design and Manufacturing Kurnool

Karthikeyan Chandrasekaran

Centro de Investigación de Polímeros Avanzados: Centro de Investigacion de Polimeros Avanzados

Mangalaraja Ramalinga Viswanathan

University of Concepción: Universidad de Concepcion

\section{Original Research}

Keywords: Mn doped ZnO, Co-precipitation method, Luminescence, Antibacterial activity, Magnetic property

Posted Date: February 10th, 2021

DOl: https://doi.org/10.21203/rs.3.rs-173208/v1

License: (c) (1) This work is licensed under a Creative Commons Attribution 4.0 International License. Read Full License

Version of Record: A version of this preprint was published at Journal of Sol-Gel Science and Technology on April 6th, 2022. See the published version at https://doi.org/10.1007/s10971-022-05778-0. 
Effect of Mn doping on the structural, optical, magnetic properties and antibacterial activity of $\mathrm{ZnO}$ nanospheres

Ebenezar Jeyasingh $^{1 *}$, Kelvin Adaikalam Charles ${ }^{1 \dagger}$, Pandiyarajan Thangaraj ${ }^{2,3}$, Karthikeyan Chandrasekaran ${ }^{4}$ and Mangalaraja Ramalinga Viswanathan ${ }^{2,5}$

${ }^{1}$ PG \& Research Department of Physics, Jamal Mohamed College (Autonomous), Tiruchirappalli - 620020, INDIA.

${ }^{2}$ Department of Materials Engineering, University of Concepcion, Concepcion, CHILE.

${ }^{3}$ Department of Sciences, Indian Institute of Information Technology, Design and Manufacturing, Kurnool, Andhra Pradesh, India.

${ }^{4}$ Centro de Investigacion de Polimeros Avanzados (CIPA), Concepcion, CHILE.

${ }^{4}$ Technological Development Unit (UDT), University of Concepcion, Coronel Industrial Park, Coronel, CHILE.

†Present Address: Department of Physics, K. Ramakrishnan College of Engineering, Tiruchirappalli - 621112, INDIA.

\section{*Corresponding authors:}

\section{Dr. Ebenezar Jeyasingh}

Assistant Professor

PG \& Research Department of Physics, Jamal Mohamed College (Autonomous), Tiruchirappalli - 620020, INDIA.

E-mail: ebey_ebenezar@yahoo.com 


\begin{abstract}
In this work, a systematic study of structural, optical, magnetic and antibacterial properties of $\mathrm{Mn}$ doped $\mathrm{ZnO}$ has been investigated. Zinc oxide $(\mathrm{ZnO})$ and $\mathrm{Mn}^{2+}$ doped zinc oxide (ZnMnO) nanoparticles (NPs) were prepared through co-precipitation method. The X-ray diffraction studies confirmed that the synthesize nanoparticles did not modify the crystal structure upon Mn doping, but the microstructural parameters were changed considerably while increasing the concentration of Mn dopant. The HRTEM images showed that the $\mathrm{ZnO}$ NPs were exhibited nanospheres like morphology and a reduction in the average particle size from $41 \mathrm{~nm}$ to $33 \mathrm{~nm}$ were observed upon $\mathrm{Mn}^{2+}$ doping. The elemental composition of $\mathrm{Zn}$, $\mathrm{Mn}$ and $\mathrm{O}$ atoms were identified by EDAX spectra. The $\mathrm{Zn}-\mathrm{O}$ stretching bands were observed at 539 and $525 \mathrm{~cm}^{-1}$ in the FTIR spectra and, the zinc and oxygen vacancies defects were confirmed by PL spectra. From the UV-Vis spectra, the band gap was estimated as 2.7 $\mathrm{eV}$ for pure and $2.9 \mathrm{eV}$ for Mn doped $\mathrm{ZnO}$ NPs. The Mn doped ZnO NPs showed greater antibacterial effect than the pure ZnO NPs. The magnetization measurements for Mn doped $\mathrm{ZnO}$ samples under room temperature ferromagnetism (RTFM) showed the ferromagnetic phase that could originated from the interactions between $\mathrm{Mn}^{2+}$ ions and oxygen vacancies and the defects incorporated in the $\mathrm{ZnO}$ matrix.
\end{abstract}

Keywords: Mn doped $\mathrm{ZnO}$; Co-precipitation method; Luminescence; Antibacterial activity; Magnetic property. 


\section{Introduction}

With the rapid development of nanotechnology, a diverse range of nanomaterials and nanoproducts are emerging [1]. $\mathrm{ZnO}$ nanoparticles, as one common engineered nanomaterial, have used in various technological field such as sunscreen products, textiles, paintings, industrial coatings, and antimicrobial agents [2, 3]. The II-VI semiconductor ZnO NPs possess the large exciton binding energy of $60 \mathrm{meV}$ and direct band gap $(3.36 \mathrm{eV})$ at room temperature, which have the promising applications in the optoelectronics and photonics [47]. The synthesis of the size and shape of the metal oxide nanostructures is significant role in controlling their physical and chemical properties for their potential application. Size of the materials becomes smaller; the band gap becomes larger, thereby changing the optical and electrical properties of the material. As a result of these changes, it is now possible to develop newer applications and devices using these materials. The modification of electrical and optical properties of a semiconductor is the generally accepted methods and it's the addition of impurity atoms or doping [8-10]. In early literature, the synthesis of $\mathrm{ZnO}$ and doped $\mathrm{ZnO}$ nanoparticles, this can be characterized into either chemical or physical method $[11,12]$, hydrothermal process [13], sol-gel method [14] and co-precipitation method [15]. Among these method of co-precipitation is suitable and preferred methods to prepare the nanoparticles. Cetin et al., (2012) reported that magnesium doped $\mathrm{ZnO}$ nanofibers has increased the band gap [16] and calcium doping in ZnO NPs has relaxed strain in the unit cell [17].

The antibacterial activity of $\mathrm{ZnO}$ NPs can be widely studied [18-21]. Commonly accepted mechanism of antibacterial action is the material production of reactive oxygen species (ROS) [22] on the surface of these NPs in the light causes oxidative stresses in bacterial cells and leads to the cell death. ROS contain the most reactive hydroxyl radical 
$(\mathrm{OH})$, less toxic superoxide anion radical $\left(\mathrm{O}^{2-}\right)$ and hydrogen peroxide with a weaker oxidizer $\left(\mathrm{H}_{2} \mathrm{O}_{2}\right)$. This can damage DNA, cell membranes etc., leading to cell death [23]. It is suggested that both $\mathrm{ZnO}$ NPs and $\mathrm{Zn}^{2+}$ are toxic but have different modes of action taking place in the antibacterial cell death. In the present investigation, pure and $\mathrm{Mn}^{2+}$ doped $\mathrm{ZnO}$ NPs are synthesized by co-precipitation method and prepared nanoparticles characterized by structural, optical, magnetic and antibacterial properties.

\section{Experimental}

\subsection{Material synthesis}

All chemicals were analytically pure and used without additional purification. The anhydrous pure zinc acetate and Sodium hydroxide of Merck Company is used. Zinc acetate $\left[\mathrm{Zn}\left(\mathrm{CH}_{3} \mathrm{COO}\right)_{2} .2 \mathrm{H}_{2} \mathrm{O}\right]$, was used as zinc sources, which provide the zinc ion for the reaction.

A chemical co-precipitation method was employed to synthesis pure and Mn doped $\mathrm{ZnO}$ NPs in colloidal solution. The synthesis was used in a zinc acetate and sodium hydroxide solution in which manganese acetate $\left[\mathrm{Mn}\left(\mathrm{CH}_{3} \mathrm{COO}\right)_{2} \cdot 2 \mathrm{H}_{2} \mathrm{O}\right]$, was added as doping agents. For pure $\mathrm{ZnO}, 2.19 \mathrm{~g}$ of zinc acetate $[0.1 \mathrm{M}]$ was dissolved in $100 \mathrm{ml}$ of distilled water and $3.2 \mathrm{~g}$ of sodium hydroxide was dissolved in $100 \mathrm{ml}$ of distilled water. Then $\mathrm{NaOH}$ solution of $3.2 \mathrm{~g}$ was added drop by drop into zinc acetate dehydrate solution until the solution reaches the white milky precipitates. The white colour precipitate was called as the zinc oxide solution. Then centrifuge the solution for $5 \mathrm{~min}$ at $3000 \mathrm{rpm}$ by repeating the process for 5 times and washed it with distilled water. The final precipitates were collected to maintain at the temperature of $90{ }^{\circ} \mathrm{C}$ for 4 to $5 \mathrm{hrs}$, to get a white coloured solid powder form of $\mathrm{ZnO}$.

Mn doped $\mathrm{ZnO}$ nanoparticles were prepared as follows: $0.024 \mathrm{~g} \mathrm{(1 \% )} 0.049 \mathrm{~g}(2 \%)$ and 0.073 $\mathrm{g}(3 \%)$ of manganese acetate was added to $100 \mathrm{ml}$ of distilled water to get the Mn solution separately, and then each solution was added to zinc acetate solution of $2.17 \mathrm{~g}, 2.15 \mathrm{~g}$ and 
$2.12 \mathrm{~g}$ respectively. Then $\mathrm{NaOH}$ solution of $3.2 \mathrm{~g}$ was added drop wise in the above each solution; it formed a dark brown precipitate. The procedure for the precipitation of undoped $\mathrm{ZnO}$ NPs was adopted for the preparation of $\mathrm{Mn}$ doped $\mathrm{ZnO}$ nanoparticles. The precipitates appeared as black coloured $\mathrm{Mn}$ doped $\mathrm{ZnO}$ samples. Finally, obtained samples were annealed at $700{ }^{\circ} \mathrm{C}$ for $2 \mathrm{hrs}$ for the energy from the heat can enhance the vibration and diffusion of lattice atoms for crystallization. The annealed nanopowder of $\mathrm{ZnO}$ will be used for further studies. The prepared pure and $\mathrm{Mn}$ doped $\mathrm{ZnO}$ samples were code named as $\mathrm{ZnO}$, $\mathrm{ZnMnO} 1, \mathrm{ZnMnO} 2$ and $\mathrm{ZnMnO}$ for $0 \%, 1 \%, 2 \%$ and 3\% of Mn concentrations, respectively.

\subsection{Instrumentation}

The $\mathrm{ZnO}$ NPs were characterized by using X-ray diffractometer (XRD model: X'PERT PRO PANalytical) for their structural analysis. The diffraction patterns were recorded in the range of $20^{\circ}-80^{\circ}$ for the $\mathrm{ZnO}$ samples where the monochromatic wavelength of $1.54 A$ was used. The morphology of the synthesized $\mathrm{ZnO}$ was examined by using highresolution transmission electron microscopy (HRTEM). The copper grid was finally dried at room temperature and was subjected to HRTEM analysis by the instrument Tecnai F20 model operated at an accelerating voltage of $200 \mathrm{kV}$. The elemental composition was done using an energy dispersive X-ray spectroscopy (EDAX model: AMETEK) with FEIQUANDA 200F HRSEM operated at $30 \mathrm{kV}$. FT-IR spectra were recorded by using PerkinElmer spectrometer through $\mathrm{KBr}$ pellet technique. The UV-Vis-NIR spectrum documented in the wavelength range $190-1110 \mathrm{~nm}$ by using Lambda 35 . The photoluminescence (PL)

measurement was performed on a spectrofluorometer (FLUROLOG-3-11, HORIBA Jobin Yvon, USA) at the excitation wavelength of $330 \mathrm{~nm}$.

\subsection{Testing of antibacterial activity}

The bacterial activity is frequently tested using a disk diffusion test, by using antibiotic filled disks (Kirby-Bauer). A related test with nanoparticle laden disks was used in 
this study. $3.8 \mathrm{~g}$ of Muller Hinton Agar (MHA) powder was dissolved in $100 \mathrm{ml}$ of water by gently boiling in a conical flask. The agar solution was sterilized by autoclaving at $15 \mathrm{lbs}$ pressure at $121^{\circ} \mathrm{C}$ for $15 \mathrm{~min}$. Then it was cooled to $40-45^{\circ} \mathrm{C}$ in a laminar hood, which was disinfected beforehand following the same method as described earlier. Nearly $20 \mathrm{~mL}$ of the above medium was added into all sterilized petri-dishes, separately after taking all precautions to avoid any contamination. The dishes were cooled for sufficient time (25-35 min) to solidify the agar medium, then a sterile cotton swab was used to inoculate the culture on surface of Muller Hinton Agar plate rotating the plate every $60^{\circ} \mathrm{C}$ to ensure homogeneous growth. The nanoparticle coated disks (6 mm diameter) were placed in each dish were made by sterilized forceps. $20 \mu \mathrm{L}$ of test solution of different concentrations were poured in each disk in two dishes. Each such dish contained two different concentrations (0.6 mg and 1.20 $\mathrm{mg}$ ) of $\mathrm{ZnO}, \mathrm{ZnMnO} 1(1 \%), \mathrm{ZnMnO} 2(2 \%) \& \mathrm{ZnMnO} 3(3 \%)$ NPs and the dishes were rapped well by a paraffin film to seal them. The entire handling was done inside the laminar hood in front of the flame of a spirit lamp. The plates were incubated at $35^{\circ} \mathrm{C}$ for $24 \mathrm{hrs}$ and the inhibition zone was measured. The mean reported for each concentration of nanoparticle and with each microbial strain were based on three replicates. Methicillin was used as positive control. All the media and disk were purchased from Hi-Media (Mumbai, India).

\section{Results and Discussion}

\subsection{XRD analysis}

Fig. 1 shows the XRD patterns of pure $\mathrm{ZnO}$ and 1\%, 2\%, 3\% Mn doped $\mathrm{ZnO}$ NPs. Patterns show strong and sharp peaks at (100), (002), (101) planes which confirm the wurtzite hexagonal structure of $\mathrm{ZnO}$ (hexagonal phase and space group $\mathrm{p} 6_{3} \mathrm{mc}$ ) with lattice constants of $\mathrm{a}=\mathrm{b}=3.249 \AA$ and $\mathrm{c}=5.206 \AA$ corresponding to JCPDS card No. 36-1451. The peaks are located at the angle $(2 \theta)$ of $31.8^{\circ}, 34.4^{\circ}, 36.3^{\circ}$, which correspond to (100), (002), (101) planes of the $\mathrm{ZnO}$; Similarly, other peaks are found in the $(2 \theta)$ angles of $47.4^{\circ}, 56.7^{\circ}, 62.9^{\circ}$, 
$66.2^{\circ}, 68.0^{\circ}, 69.2^{\circ}, 72.4^{\circ}$ and $77.3^{\circ}$, corresponding to (102), (110), (103), (200), (112), (201), (004) and (202) planes of the wurtzite structure, respectively. Interesting Mn doped samples show no secondary peaks, which confirm there is no secondary phase formation, but there is a slight lower angle shift compared to undoped $\mathrm{ZnO}$ NPs diffraction pattern and further the intensities are decreased with increasing the concentration of Mn.

\section{Particle size determination:}

The particle size of the pure and $\mathrm{Mn}$ doped $\mathrm{ZnO}$ can be calculated using DebeyScherer's formula:

$$
D=\frac{k \lambda}{\beta_{h k l} \cos \theta}
$$

where the constant $k$ is the shape factor $=0.94, \lambda$ is the wavelength of $X$-rays $(1.5418$ for $\mathrm{Cu}$ $K \alpha$ ), $\theta$ is Bragg's angle, $\beta$ is the full width at the half- maximum (FWHM). The particle size of the pure $\mathrm{ZnO}$ was calculated as $41.6 \mathrm{~nm}$ and when the dopant manganese was added to pure $\mathrm{ZnO}$, the crystallite size of the NPs gets decreased to 40.1 and $33.8 \mathrm{~nm}$ for $\mathrm{ZnMnO} 2$ and ZnMnO3, respectively. Staumal et al. [24] investigated that the decrease of crystallite size is due to increase of $\mathrm{Mn}$ solubility in $\mathrm{ZnO}$. However, in all the Mn doped samples, the particle size gets reduced gradually with increasing of Mn concentration [Table 2].

The lattice parameters of $\mathrm{ZnO}$ nanostructures are highly depend on the doping concentrations since there is difference of dopant ionic radius with respect to the $\mathrm{ZnO}$ matrix.

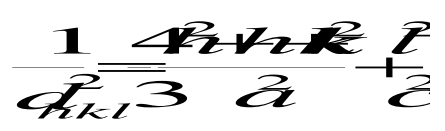

with the first order approximation $(n=1)$ for the (100) plane the lattice constant ' $a$ ' is obtained through the relation $a=\frac{\lambda}{\sqrt{3} \operatorname{sir} 6}$ and the lattice constant 'c' can be derived for the plane 
(002) by the relation $c=\frac{\lambda}{\sin \theta}$ and unit cell volume could be deduced from the formulae [25] $v=\frac{\sqrt{3} a^{2} c}{2}$. The dopant induced change in the bond length was deduced from the relation [26] $L=\sqrt{\left(\frac{a^{2}}{3}\right)+\left(\frac{1}{2}-u_{p}\right)^{2} c^{2}}$ where, ' $a$ ', and ' $c$ ' are lattice parameters and ' $u_{p}$ ' is the positional parameter which can be calculated by the formula $u_{p}=\left(\frac{a^{2}}{3 c^{2}}\right)+0.25$. The calculated lattice constants and bond length is shown in Fig. 2a and b. It shows an increase in lattice constant due to $\mathrm{Mn}$ doping. The lattice constants of $\mathrm{Mn}$ doped $\mathrm{ZnO}$ were more than that of undoped $\mathrm{ZnO}$, because of the ionic radius of $\mathrm{Mn}^{2+}(0.66 \AA)$ is larger than that of $\mathrm{Zn}^{2+}$ $(0.74 \AA)[27]$.

The dopant induced lattice strain can be extracted from the peak broadening of diffraction line. The peak broadening of diffraction line is due to the combination of lattice strain and the particle size with respect to diffraction angle and it can be written as $\beta_{h k l}=\beta_{t}+\beta_{e}[28]$ where $\beta_{t}$ is line broadening due to the particle size and $\beta_{e}$ is due to the strain induced by dopant ions. The particle size could be evaluated by using the Scherrer formula and peak broadening due to strain can be calculated $\beta_{e}=4 \varepsilon \tan \theta$ where $\varepsilon$ is the microstrain. The peak broadening due to the combination of particle size as well as microstrain can be written mathematically [29] $\beta_{h k l} \cos \theta_{h k l}=\frac{k \lambda}{D}+4 \varepsilon \sin \theta$. The microstarin was extracted from the plot of $\beta_{h k l} \cos \theta_{h k l}$ vs $4 \sin \theta$ (Fig. 3a). The variation in the microstarin upon Mn concentration is plotted and shown in Figure $3 \mathrm{~b}$. The results revealed that the up to $2 \%$ of Mn concentration, the microstrain is decreased with respect to the pure $\mathrm{ZnO}$ and increases for $3 \%$ of $\mathrm{Mn}$ concentration. This is due to lattice mismatch when the concentration of $\mathrm{Mn}$ is large [30]. 


\subsection{HRTEM studies}

The ordered lattice fringes in the HRTEM image further confirmed the single crystalline nature of pure $\mathrm{ZnO}$ and $\mathrm{Mn}$ doped $\mathrm{ZnO}$ NPs. Fig. 4.1 (a-d) shows the distribution of spherical shaped pure ZnO NPs. Fig. 4.2 (a-d) it's seen that images found from the portion of an individual $\mathrm{ZnMnO}$ particle confirms the better crystalline nature of $\mathrm{ZnMnO}$ NPs. Further, by the image analyzer software IMAGE-J on the lattice resolved TEM image, the distance between two parallel planes were observed at $\sim 0.26 \mathrm{~nm}$. Corresponding selected area electron diffraction (SAED) pattern of pure and manganese doped $\mathrm{ZnO}$ NPs is shown in Fig. $4.1 \& 4.2$ (a-d). The superimpositions of the bright spots indicate the good crystalline nature of the samples with equal lattice arrangement.

\subsection{EDAX analysis}

The EDAX spectra of the pure $\mathrm{ZnO}, \mathrm{ZnMnO} 1, \mathrm{ZnMnO} 2$ and $\mathrm{ZnMnO} 3$ NPs are shown in Fig. 5 (a-d). From the EDAX spectra, the amounts of Zn, Mn, O atoms that present in the samples are given in Table 2. In the pure $\mathrm{ZnO}$ NPs, the chemical compositions of $\mathrm{Zn}$ and $\mathrm{O}$ were observed at 59.25 and $40.75 \%$ and for the doped $\mathrm{ZnO}$ NPs the Mn concentrations are $0.53,1.04$ and $1.91 \%$ for $\mathrm{ZnMnO} 1, \mathrm{ZnMnO} 2$ and $\mathrm{ZnMnO} 3 \mathrm{NPs}$, respectively. Whereas, in the Mn doped $\mathrm{ZnO}$ NPs, the zinc percentage decreases with the increasing percentage of oxygen depending on the increasing doping concentrations.

\subsection{UV spectroscopy analysis}

The UV-Vis absorption spectra of the pure and Mn doped ZnO NPs samples were done by dispersing $3 \mathrm{mg}$ of powder in $10 \mathrm{~mL}$ water and the spectrum is shown in Fig. 6 . The absorbance is expected to depend on some factors like band gap, oxygen deficiency, surface roughness and impurity centres [27]. The absorbance spectra exhibit an absorption edges 
around $350-380 \mathrm{~nm}$, this is due to the photo-excitation of electrons from valence band to conduction band. The absorption edge of different samples slightly varies as the concentration of $\mathrm{Mn}$ in the $\mathrm{ZnO}$ nanoparticles fluctuates. The absorption edges of pure and 1, 2 and 3\% Mn doped $\mathrm{ZnO}$ are 376, 374, 374 and $373 \mathrm{~nm}$, respectively. The absorption edges position is to shift toward the lower wavelength side, with increasing the concentration of Mn doping in $\mathrm{ZnO}$. The band gap of $\mathrm{ZnO}$ NPs increases with doping concentration of $\mathrm{Mn}$ ions and blue shift while doping ions in semiconductors, which can be described on the basis of the Burstein-Moss effect [30]. The blue shift may be attributed due to agglomeration in the sample [28-29].

\subsubsection{Estimation of optical bandgap}

The optical bandgap of the synthesized $\mathrm{ZnO}$ and $\mathrm{Mn}$ doped $\mathrm{ZnO}$ nanoparticles can be calculated using from this relation,

$$
\alpha=2.303 \frac{\mathrm{A}}{\mathrm{t}}
$$

Where $\mathbf{A}$ is the absorbance and $\mathbf{t}$ is the thickness of the cuvette. The optical band gap of the NPs was determined by applying the Tauc relationship given by,

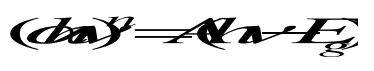

Where $\mathbf{A}$ is a constant, $\mathbf{h}$ is Planck's constant, $\boldsymbol{v}$ is the photon frequency, $\mathbf{E} \mathbf{g}$ is the optical band gap and $\mathbf{n = 1 / 2}$ for direct bandgap semiconductor. An extrapolation of the linear region of a plot of $(\boldsymbol{\alpha h v})^{2}$ on the Y-axis vs. Photon energy (hv) on the X-axis gives the value of the optical band gap $\left(\mathbf{E}_{\mathbf{g}}\right)$.

The bandgap of undoped and $\mathrm{Mn}$ doped $\mathrm{ZnO}$ samples is measured by extrapolation of linear portion of the graph between the kublka-munk function $(h v \alpha)^{2}$ Vs (hv) [27]. Fig. 7 
shows the band gap energy diagram for pure and $\mathrm{Mn}$ doped $\mathrm{ZnO}$ nanoparticles. The calculated bandgap of pure $\mathrm{ZnO}$ nanoparticles was found to be $2.7 \mathrm{eV}$ while in the case of Mn doped $\mathrm{ZnO}$ it was at $2.9 \mathrm{eV}$. The band gap energy of $\mathrm{ZnO}$ increases with the addition of $\mathrm{Mn}$ (except $\mathrm{ZnMnO} 2$ ). This is attributed to the increase in particle size of doped $\mathrm{ZnO}$. It's clear that more level of doping (except $\mathrm{ZnMnO} 2$ ) causes an increase in the exitonic bandgap, proving the Burstein-Moss effect [26].

\subsection{Photoluminescence (PL) analysis}

Generally, the densities of defects and oxygen vacancies affect significantly the optical properties of oxide nanostructures. The correlation between structure and property is investigated by PL spectra of undoped and $\mathrm{Mn}$ doped $\mathrm{ZnO}$ nanoparticles excitation wavelength of $325 \mathrm{~nm}$ at room temperature is shown in Fig. 8. The PL spectra of the samples $\mathrm{ZnO}, \mathrm{ZnMnO} 1, \mathrm{ZnMnO} 2$ and $\mathrm{ZnMnO} 3$ NPs demonstration a UV emission peak at $~ 387$ to $397 \mathrm{~nm}$ and broad visible emission peaks including violet emission at $\sim 416$ to $418 \mathrm{~nm}$, bluegreen emission at $\sim 480$ to $479 \mathrm{~nm}$ and green emission at $\sim 523$ to $524 \mathrm{~nm}$. The UV emission band is associated to near band-edge (NBE) emission of the ZnO NPs, and is due to the recombination of free excitons by exciton-exciton collision process [31, 32]. Several authors have investigated the PL properties of $\mathrm{ZnO}$ nanostructures [31-38]. Generally, visible emission in $\mathrm{ZnO}$ contains of blue, violet, green and yellow emission peaks, this may be ascribed to many intrinsic defects such as oxygen vacancies $\left(V_{o}\right)$, zinc vacancies $\left(V_{Z n}\right)$, oxygen interstitials $\left(O_{i}\right)$, zinc interstitials $\left(Z n_{i}\right)$ and oxygen antisites $\left(O_{Z n}\right)$ [30]. UV peak is shifted from 394 to $387 \mathrm{~nm}$ with respect to the Mn concentrations (Fig. 8b), that shows the result is consistent with UV absorption spectra.

The violet emission in synthesized $\mathrm{ZnO}$ NPs centered at $\sim 416$ to $\sim 418 \mathrm{~nm}$ is attributed to an electron transition from a shallow donor level of the neutral $Z n_{i}$ to the top level of the 
valence band [39]. A blue-green emission observed at $\sim 480$ to $479 \mathrm{~nm}$ is due to a radiative transition of an electron from the shallow donor level of $Z n_{i}$ to an acceptor level of neutral $V z_{n}$ [31]. The green emission at $\sim 523$ to $524 \mathrm{~nm}$ is attributed to radiative transition from conduction band to the edge of the acceptor levels of $\mathrm{Oz}_{n}$ caused by oxygen antisites $\left(\mathrm{O} z_{n}\right)$ $[31,40]$. The UV emission and reduced visible emission shows that the undoped and Mn doped $\mathrm{ZnO}$ NPs have a good crystal structure with fewer oxygen vacancies.

\subsection{FT-IR analysis}

FTIR spectra of pure and $\mathrm{Mn}$ doped $\mathrm{ZnO}$ nanoparticles are shown in Fig.9. FTIR spectra for all the samples are assigned at room temperature. The $\mathrm{Zn}-\mathrm{O}$ stretching frequency observed at $539 \mathrm{~cm}^{-1}$ for pure $\mathrm{ZnO}$ which is shifted to lower frequency as $525 \mathrm{~cm}^{-1}$ for $\mathrm{Mn}=$ $0.01 \mathrm{M}, 525 \mathrm{~cm}^{-1}$ for $\mathrm{Mn}=0.02 \mathrm{M}$ and $525 \mathrm{~cm}^{-1}$ for $\mathrm{Mn}=0.03 \mathrm{M}$. The $\mathrm{C}=\mathrm{O}$ stretching bands at $1500-1650$ and at $2344,2330,2358 \mathrm{~cm}^{-1}$ are arising from the absorption of atmospheric $\mathrm{CO}_{2}$ [41]. The bands around 1200 and $1100 \mathrm{~cm}^{-1}$ are attributed to the characteristic frequency of inorganic ions. The additional bands are observed at $1406 \mathrm{~cm}^{-1}$, due to the microstructural formation of the sample. The wide absorption peaks in the range of $3410-3465 \mathrm{~cm}^{-1}$, related to the $-\mathrm{OH}$ group, may due to the water adsorbed on the surface of nanoparticles.

\subsection{Antibacterial Properties}

At present the nanoparticles are being extensively studied to antibacterial activity. Several factors such as reduced amount of toxicity level and heat resistance are accountable for the use of NPs in the biological applications [42, 43]. The pure and Mn doped $\mathrm{ZnO}$ nanoparticles are investigated with respect to potential antimicrobial applications. The microbial sensitivity to the nanoparticles is found to vary depending on the microbial species and also due to $\mathrm{ZnO}$ and $\mathrm{Mn}$ concentrations. The bactericidal effect of the nanoparticles of pure and $\mathrm{Mn}$ doped $\mathrm{ZnO}$ is tested against harmful micro organisms. The two tested concentrations of 0.6 and $1.20 \mathrm{mg} /$ disk produce zone of inhibition. The antimicrobial activity 
of pure and $\mathrm{Mn}$ doped $\mathrm{ZnO}$ is scrutinized with two micro organisms (S. epidermidis \& $P$. aeruginosa) using the disk diffusion test.

Figs. 10 (a) and (b) show the development of antibacterial activity of pure $\mathrm{ZnO}$ and Mn doped $\mathrm{ZnO}$ NPs. ZnO and $\mathrm{Mn}$ doped $\mathrm{ZnO}$ NPs exhibit antibacterial activity as shown in Figs. 9 (a) and (b). As said earlier, the higher ROS is generally produced to the decreasing particles size, larger surface area, diffusion ability of the reactant molecules and increase in oxygen vacancies. In present work, the antimicrobial activity of the ZnO NPs is essentially attributed to the combination of several factors such as ROS, and the release of $\mathrm{Zn}^{2+}$.

The above mechanism of light induced generation of ROS can be given in equation form as following [43],

$$
\begin{gathered}
\mathrm{ZnO}+\mathrm{hv} \rightarrow \mathrm{e}^{-}+\mathrm{h}^{+} \\
\mathrm{h}^{+}+\mathrm{H}_{2} \mathrm{O} \rightarrow \mathrm{OH}+\mathrm{H}^{+} \\
\mathrm{e}^{-}+\mathrm{O}_{2} \rightarrow \cdot \mathrm{O}_{2}^{-} \\
\bullet \mathrm{O}_{2}^{-}+\mathrm{H}^{+} \rightarrow \mathrm{HO}_{2} \cdot \\
\mathrm{HO}_{2} \bullet+\mathrm{H}^{+} \rightarrow \mathrm{H}_{2} \mathrm{O}_{2}
\end{gathered}
$$

From the result of photoluminescence studies for $\mathrm{ZnO}$ and $\mathrm{Mn}$ doped $\mathrm{ZnO}$ NPs, the violet and blue-green emissions can have the possibility of interstitial incorporation of $\mathrm{Mn}$ and $\mathrm{Zn}$ ions into the $\mathrm{ZnO}$ lattice. The second reason for the antibacterial activity is that when $\mathrm{Zn}^{2+}$ released by $\mathrm{ZnO}$ contacts with the cell membranes of microbe, the cell membranes with negative electricity and $\mathrm{Zn}^{2+}$ with positive electricity attract mutually and then the $\mathrm{Zn}^{2+}$ would penetrate into the cell membranes and react with sulfhydryl inside the cell membranes. As a result, the activity of synthetase in the microbe is so damaged that the cells lose the ability of division growth, which leads to death of the microbe. 
Moreover, the antimicrobial activity and unreleased of $\mathrm{Mn}^{2+}$ ions cannot be accountable for the biocide activity of the Mn doped sample. But the replacement of $\mathrm{Mn}$ in the $\mathrm{Zn}$ site enhanced the photoactivity of the particles as related to ZnO NPs because of the similarity in ionic radii between $\mathrm{Mn}^{2+}(0.66 \AA)$ and $\mathrm{Zn}^{2+}(0.74 \AA)$. From the PL spectra of pure and $\mathrm{Mn}$ doped $\mathrm{ZnO}$, the wavelengths of green emissions are at 523 and $524 \mathrm{~nm}$. These indications increased the oxygen vacancies in the Mn doped $\mathrm{ZnO}$ NPs leading to more ROS as compared to that of $\mathrm{ZnO}$ NPs.

The NPs with uneven surfaces and rough edges have adhered to the bacterial wall and these causes damage to the cell membrane [44]. From the flied emission scanning electron microscopy (FESEM) image, the Mn doped ZnO NPs have uneven ridges and cluster formations at their outer surface leading to antibacterial activity.

Normally, bactericidal agents are potential to inhibit in the clinical field because bactericides lead to rapid and better recovery from the bacterial infection and such as minimize the risk of the emergence of drug resistance [45].

Interestingly in the present study the zone of inhibition reflects the degree of susceptibility of the microorganism. The strains incorporated to the disinfectants exhibit larger inhibition zone, whereas resistant strains exhibit smaller inhibition zone (see Fig.11). All the bacterial strains depict higher sensitivity to the higher concentration $(1.2 \mathrm{mg} / \mathrm{ml})$ for both Pure $\mathrm{ZnO}$ and $\mathrm{Mn}$ doped $\mathrm{ZnO}$ NPs. When compared to the positive control Methicillin $(10 \mathrm{mg} / \mathrm{ml})$, except $S$. epidermis, it exhibits larger zone of inhibition than the positive control at pure $\mathrm{ZnO}$ and $\mathrm{Mn}$ doped $\mathrm{ZnO}$ NPs.

\section{8 Magnetic properties}

The influence of pure and Mn doped ZnO NPs on the magnetic properties are studied. The undoped $\mathrm{ZnO}$ NPs is existence with diamagnetic behaviour at magnetic moment 0.0096 
emu/g and also observed that the magnetic moment $(0.00809,0.0304$ and $0.0408 \mathrm{emu} / \mathrm{g})$ of Mn doped ZnO NPs increased with the increase of Mn doping concentration (Fig. 12). The alterations in the $\mathrm{M}-\mathrm{H}$ loop has been described based on the magnetic contribution from the alignment of strong exchange interaction in $d-d$ couple with manganese ion concentration in the BMP model, suggesting that the $\mathrm{Mn}^{2+}$ ion contributes to the ferromagnetism of Mn-doped $\mathrm{ZnO}$ nanoparticles [6,44]. The strain was increased significantly with the addition of antiferromagnetic $\mathrm{Mn}^{2+}$. At high $\mathrm{Mn}$ concentrations the strain is notably high and accompanies the RTFM. Increase of Mn doping concentration enhances the linear behaviour of the M-H loop. In 1\%, 2\% and 3\% Mn doped $\mathrm{ZnO}$ NPs, there is no formation of a strong ferromagnetic coupling among the transition metal cations $\left(\mathrm{Mn}^{2+}\right)$ at the microscopic level. Hence, the possibility of strong ferromagnetic behaviour_of $\mathrm{Mn}$ doped $\mathrm{ZnO}$ is ruled out, but it results to the weak ferromagnetic or super-paramagnetic behaviour.

\section{Conclusion}

The pure $\mathrm{ZnO}$ and $\mathrm{Mn}$ doped $\mathrm{ZnO}$ NPs were synthesized by the co-precipitation method. The X-ray diffraction (XRD) results confirmed that the synthesized NPs formed with hexagonal wurtzite structure. The HRTEM images of the synthesized NPs showed nanospheres morphology and a reduction in the particle size with respect to the $\mathrm{Mn}$ concentrations. The bandgap of $\mathrm{ZnO}$ NPs was increased from 2.7 to $2.9 \mathrm{eV}$ upon Mn doping. The antibacterial studies were performed against a set of bacterial strains. Among them, Staphylococcus epidermidis showed the higher sensitivity to $\mathrm{Mn}$ doped $\mathrm{ZnO}$ nanoparticles which were powerful than the positive control and Pseudomonas aeruginosa strain was less sensitive to NPs. 


\section{$\underline{\text { Declarations }}$}

Funding - Not Applicable

Conflicts of interest/Competing interests: Authors declared no conflict of interest

Availability of data and material - Not Applicable

Code availability- Not Applicable

Additional declarations for articles in life science journals that report the results of studies involving humans and/or animals - Not Applicable

Ethics approval- Not Applicable

\section{References}

1. R. D. Handy, F. Von der Kammer, J. R. Lead, M. Hassellöv, R. Owen, M. Crane, Ecotoxicology, 17, 287 (2008).

2. N.M. Franklin, N.J. Rogers, S.C. Apte, G.E. Batley, G.E. Gadd, P.S. Casey, Environ. Sci Tech, 41, 8484 (2007).

3. Y. Liu, L. He, A.Mustapha, L. Hi, Z. Q. Hu, M. Lin, J. Appl. Microbio, 107, 1193 (2009).

4. S. Singh, M.R. Rao, Phys. Rev B, 80, 045210(2009).

5. J. Alaria, P. Turek, M. Bernard, M. Bouloudenine, A. Berbadj, N. Brihi, A. Dinia, Chem Phys Lett, 415, 337 (2005).

6. V. Gandhi, R. Ganesan, H.H. Abdulrahman Syedahamed, M. Thaiyan, J Phys Chem C, 118, 9715 (2014).

7. M.H. Sluiter, Y. Kawazoe, P. Sharma, A. Inoue, A. Raju, C. Rout, U.V. Waghmare, Phys Rev Lett, 94, 187204 (2005).

8. L. Hsu, C.S. Yeh, C.C. Kuo, B.R. Huang, S. Dhar, J. Optoelectronics Advan Mater, 7, 3039 (2005).

9. R.N. Bhargava, D. Haranath, A. Mehta, J Korean Phys. Soc, 53, 2847 (2008).

10. S.Y. Bae, C.W. Na, J.H. Kang, J. Park, J Phys Chem B, 109, 2526 (2005).

11. I. Djerdj, Z. Jagličić, D. Arčon, M. Niederberger, Nanoscale, 2, 1096 (2010).

12. I. Djerdj, G. Garnweitner, D. Arčon, M. Pregelj, Z. Jagličić, M. Niederberger, J Mater Chem, 18, 5208 (2008).

13. S.I. Hirano, American Ceram Soc Bulletin, 66, 1342 (1987).

14. D. Vorkapic, T. Matsoukas, T. J Amer. Ceram. Soc, 81, 2815 (1998).

15. P.S. Patel, M.V. Hathi, J. Chem. Pharm. Res, 2, 78 (2010)

16. S.S. Cetin, I. Uslu, A. Aytimur, S. Ozcelik, Ceram Inter, 38, 4201 (2012). 
17. B. Karthikeyan, T. Pandiyarajan, K. Mangaiyarkarasi, Spectrochimica Acta Part A:, 82, 97 (2011).

18. R. Brayner, R. Ferrari-Iliou, N. Brivois, S. Djediat, M.F. Benedetti, F. Fiévet, Nano lett, 6, 866 (2006).

19. M. Li, L. Zhu, D. Lin, Environ. Sci Techn, 45, 1977 (2011).

20. N. Talebian, S.M. Amininezhad, M. Doudi, J. Photochem Photobio B: Biology, 120, 66 (2013).

21. G.X. Tong, F.F. Du, Y. Liang, Q. Hu, R.N. Wu, J.G. Guan, X. Hu, J. Mater. Chem $B, 1,454$ (2013).

22. G. Vijayaprasath, R. Murugan, S. Palanisamy, N.M Prabhu, T. Mahalingam, Y. Hayakawa, G. Ravi, J. Mater. Sci: Mater. Electron, 26, 7564 (2015).

23. H.A. Foster, I.B. Ditta, S. Varghese, A. Steele, Appl Microbio Biotechn, 90, 1847 (2011).

24. B. Staumal, B. Baretzky, A. Mazilkin, S.Protasava, A. Petrastraumal, J. European Ceramic Soc JECS 29, 1963 (2009)

25. Suryanarayana, C., \& Norton, M. G. X-ray diffraction: a practical approach. Springer Science \& Business Media (2013).

26. P. Singh, A. Kaushal, D. Kaur, J. Alloys Compd, 471, 11 (2009).

27. S. Suwanboon, T. Ratana, T. Ratana, J. Walailak J. Sci. Techn (WJST), 4, 111 (2007).

28. M. Vafaee, M.S. Ghamsari, Mater Lett, 61, 3265 (2007).

29. W. Xie, X. Huang, Cataly Lett, 107, 53 (2006).

30. A. Hernández, L.Maya, E. Sánchez-Mora, E.M. Sánchez, J. Sol-Gel Sci. Tech, 42, 71 (2007).

31. S.K. Mishra, R.K. Srivastava, S.G. Prakash, J. Alloys Compd, 539, 1 (2012).

32. S.K. Mishra, R.K. Srivastava, S.G. Prakash, R.S. Yadav, A.C. Panday, OptoElectronics Rev, 18, 467 (2010).

33. K. Vanheusden, W.L. Warren, C.H. Seager, D.R. Tallant, J.A. Voigt, B.E Gnade, J. Appl Phys, 79, 7983 (1996).

34. Z.M. Liao, H.Z. Zhang, Y.B. Zhou, J. Xu, J.M. Zhang, D.P. Yu, Phys Lett A, 372, 4505 (2008).

35. J.C. Johnson, K.P. Knutsen, K. P H. Yan, M. Law, Y. Zhang, P. Yang, R.J. Saykally, Nano Lett, 4, 197 (2004).

36. Z. Fan, P.C. Chang, J.G. Lu, E.C. Walter, R.M. Penner, C.H. Lin, H. P. Lee, Appl phy lett, 85, 6128 (2004). 
37. L. Wischmeier, C. Bekeny, T. Voss, S. Börner, W. Schade, W. physica status solidi (b), 243, 919 (2006).

38. I. Shalish, H. Temkin, V. Narayanamurti, Phys Rev B, 69, 245401 (2004).

39. J. Grabowska, A.Meaney, K. K.Nanda, J.P. Mosnier, M.O. Henry, J.R. Duclère, E. McGlynn, Phys Rev B, 71, 115439 (2005).

40. J. Wang, L. Gao, J. Mater Chem, 13, 2551-2554 (2003).

41. C. F.Jin, X.Yuan, W. W.Ge, J. M. Hong, X. Q. Xin, Nanotech, 14, 667 (2003).

42. S. B. Qadri, E. F. Skelton, D. Hsu, A.D. Dinsmore, J. Yang, H. F. Gray, B.R. Ratna, Phys Rev B, 60, 9191 (1999).

43. R. Prasad, G. Rattan, Bulletin of Chemical Reaction Engineering \& Catalysis, 5, 7 (2010).

44. R. Brayner, R. Ferrari-Iliou, N.Brivois, S.Djediat, M. F. Benedetti, F. Fiévet, Nano lett, 6, 866 (2006).

45. G. Vijayaprasath, R. Murugan, S. Palanisamy, N.M. Prabhu, T. Mahalingam, Y. Hayakawa, G. Ravi, Mater Res Bullet., 76, 48 (2016)

46. G. L. French, J. Antimicrobial Chemotherapy, 58, 1107 (2006). 


\section{Figure captions}

Fig. 1: X-ray diffraction patterns of pure $\mathrm{ZnO}, \mathrm{ZnMnO} 1, \mathrm{ZnMnO} 2, \mathrm{ZnMnO} 3$ samples.

Fig. 2 (a): Variation of lattice parameters 'a' and 'c' with Mn concentrations. (b) Variation of unit cell volume and bond length with Mn concentration

Fig. 3. (a): The $\mathrm{W}-\mathrm{H}$ analysis of pure and $\mathrm{Mn}$ doped $\mathrm{ZnO}$ nanoparticles (b) Variation of microstrain along with the Mn concentrations

Fig. 4.1 (a-d): HRTEM images and SAED pattern of Pure ZnO Nanoparticles.

Fig. 4.2 (a-d): HRTEM images and SAED pattern of ( $\mathrm{ZnMnO} 2) \mathrm{Mn}$ doped $\mathrm{ZnO}$

Nanoparticles

Fig. 5 (a-d): EDAX spectrum for pure $\mathrm{ZnO}$ and different concentration of $\mathrm{Mn}$ doped $\mathrm{ZnO}$ nanoparticles.

Fig. 6: $\mathrm{UV}$ absorption spectra of pure $\mathrm{ZnO}$ and different $\mathrm{Mn}$ concentration of $\mathrm{ZnO}$ nanoparticles.

Fig. 7: Shows band gap energy of $\mathrm{ZnO}$ and $\mathrm{Mn}$ doped $\mathrm{ZnO}$ Nanoparticles

Fig.8: (a) Lorentzian decomposed photoluminescence spectra of $\mathrm{ZnO}$ and $\mathrm{Mn}$ doped $\mathrm{ZnO}$ nanoparticles and (b) variation in the UV peak position with respect to the $\mathrm{Mn}$ concentrations

Fig .9: FTIR spectra of $\mathrm{ZnO}$ and $\mathrm{Mn}$ doped $\mathrm{ZnO}$ Nanoparticles

Fig. 10: The zone of inhibition formed around each disc, loaded with test samples indicated the antimicrobial activity of (a) Staphylococcus epidermidis and (b) Pseudomonas aeruginosa.

Fig. 11: The zone of inhibition formed around each disc, loaded with test samples indicated the antibacterial activity of (a) S. Epidermis and (b) P. aeruginosa.

Fig. 12: Magnetization curves loops for $\mathrm{ZnO}$ and $\mathrm{Mn}$ doped $\mathrm{ZnO}$ Nanoparticles 
Table -1. Sample coding and Sample composition:

\begin{tabular}{|c|c|c|}
\hline S.no & Sample Coding & Sample Composition \\
\hline 1. & $\begin{array}{l}\text { Pure } \mathrm{ZnO} \\
(\mathrm{Zn}-100 \%)\end{array}$ & $0.100 \mathrm{M} \mathrm{Zn}\left(\mathrm{CH}_{3} \mathrm{COO}\right)_{2} \cdot \mathrm{H}_{2} \mathrm{O}+0.8 \mathrm{M} \mathrm{NaOH}$ \\
\hline 2. & $\begin{array}{c}\text { ZnMnO1 } \\
(\mathrm{Zn}-\mathbf{9 9 \%} \& \mathrm{Mn}-1 \%)\end{array}$ & $\begin{array}{l}0.099 \mathrm{M} \mathrm{Zn}\left(\mathrm{CH}_{3} \mathrm{COO}\right)_{2} \cdot \mathrm{H}_{2} \mathrm{O}+0.8 \mathrm{M} \mathrm{NaOH}+0.001 \mathrm{M} \\
\mathrm{Mn}\left(\mathrm{CH}_{3} \mathrm{COO}\right)_{2} . \mathrm{H}_{2} \mathrm{O}\end{array}$ \\
\hline 3. & $\begin{array}{c}\mathrm{ZnMnO2} \\
(\mathrm{Zn}-\mathbf{9 8 \%} \& \mathrm{Mn}-\mathbf{2 \%})\end{array}$ & $\begin{array}{l}0.098 \mathrm{M} \mathrm{Zn}\left(\mathrm{CH}_{3} \mathrm{COO}\right)_{2} . \mathrm{H}_{2} \mathrm{O}+0.8 \mathrm{M} \mathrm{NaOH}+0.002 \mathrm{M} \\
\mathrm{Mn}\left(\mathrm{CH}_{3} \mathrm{COO}\right)_{2} . \mathrm{H}_{2} \mathrm{O}\end{array}$ \\
\hline 4. & $\begin{array}{c}\mathrm{ZnMnO3} \\
(\mathrm{Zn}-97 \% \& \mathrm{Mn}-3 \%)\end{array}$ & $\begin{array}{l}0.097 \mathrm{M} \mathrm{Zn}\left(\mathrm{CH}_{3} \mathrm{COO}\right)_{2} . \mathrm{H}_{2} \mathrm{O}+0.8 \mathrm{M} \mathrm{NaOH}+0.003 \mathrm{M} \\
\mathrm{Mn}\left(\mathrm{CH}_{3} \mathrm{COO}\right)_{2} \cdot \mathrm{H}_{2} \mathrm{O}\end{array}$ \\
\hline
\end{tabular}


Table-2. Particle size and lattice parameter values of $\mathrm{ZnO}$ and $\mathrm{Mn}$ doped $\mathrm{ZnO}$ Nanoparticles

\begin{tabular}{cccc}
\hline Samples & Particle size $(\mathbf{n m})$ & $\mathbf{a}(\AA)$ & $\mathbf{c}(\AA)$ \\
\hline Pure ZnO & 41.8 & 3.2438 & 5.1985 \\
ZnMnO1 & 41.2 & 3.3038 & 5.2857 \\
ZnMnO2 & 40.1 & 3.3027 & 5.2847 \\
ZnMnO3 & 33.8 & 3.3074 & 5.2940 \\
\hline
\end{tabular}


Table-3. Compositional analysis of $\mathrm{ZnO}$ and $\mathrm{ZnMnO}$ NPs

\begin{tabular}{ccccc}
\hline \multirow{2}{*}{ Sample } & $\begin{array}{c}\text { Dopant } \\
\text { concentration }\end{array}$ & \multicolumn{2}{c}{ Experimental results (Atomic \%) } \\
\cline { 2 - 4 } & & Zn & Mn & O \\
ZnO & 0 & 59.25 & - & 40.75 \\
ZnMnO1 & 1 & & & \\
ZnMnO2 & 2 & 40.22 & 0.53 & 59.25 \\
ZnMnO3 & & & & 54.15 \\
& 3 & 44.81 & 1.04 & 57.48 \\
\hline
\end{tabular}


Figures

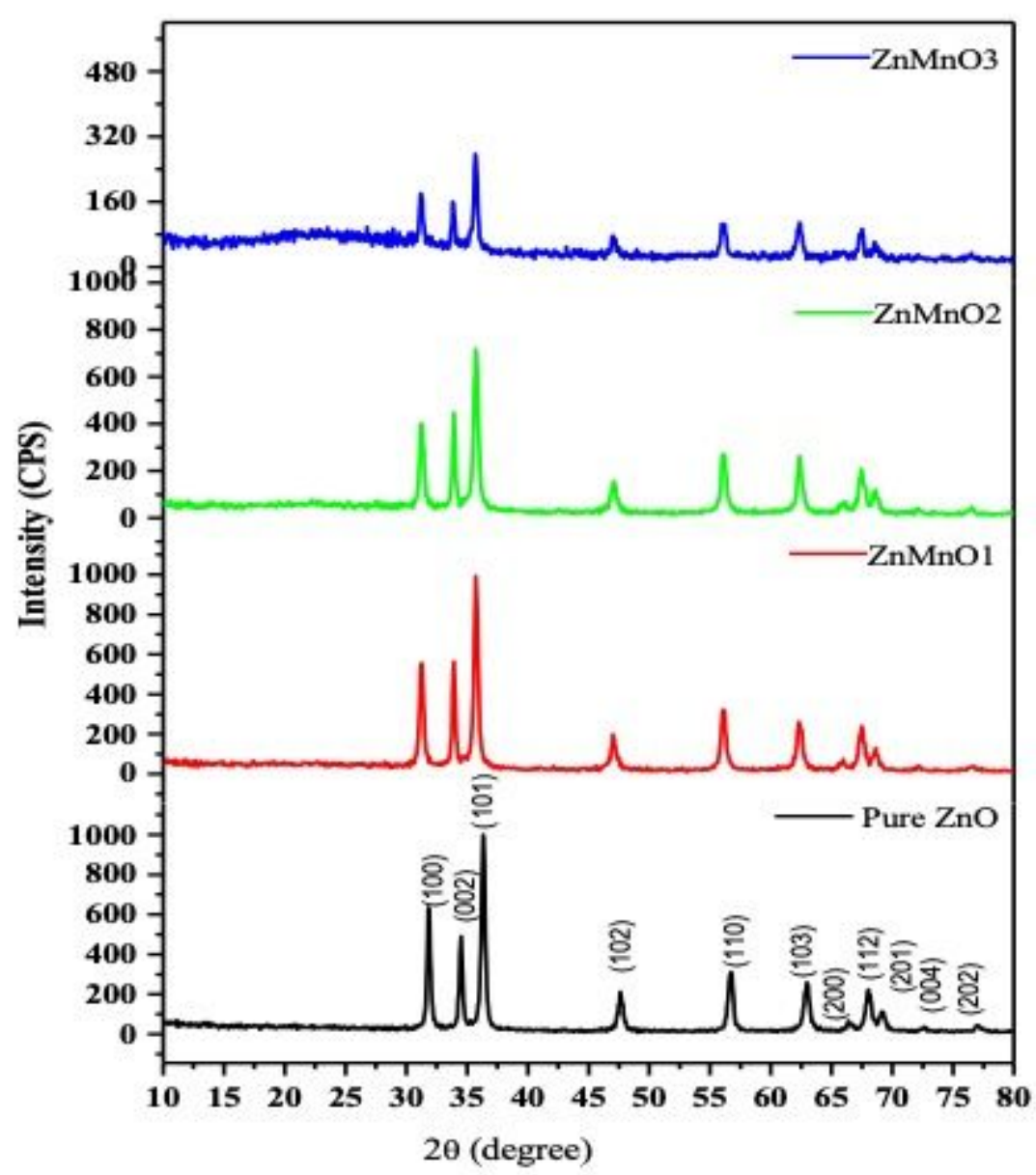

Figure 1

X-ray diffraction patterns of pure $\mathrm{ZnO}, \mathrm{ZnMnO1}, \mathrm{ZnMnO2,} \mathrm{ZnMnO3}$ samples. 


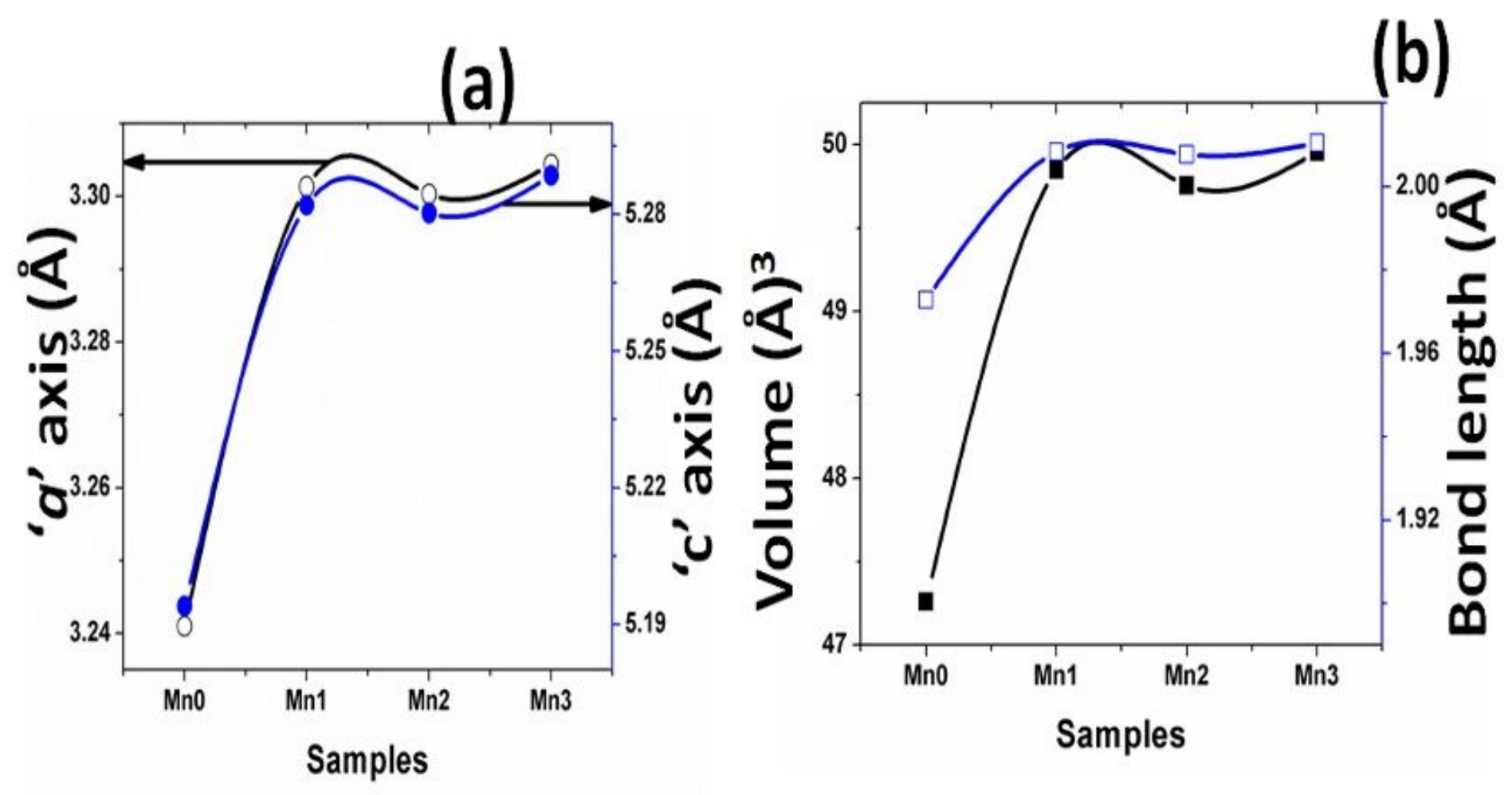

Figure 2

(a): Variation of lattice parameters 'a' and 'c' with Mn concentrations. (b) Variation of unit cell volume and bond length with Mn concentration

(a)

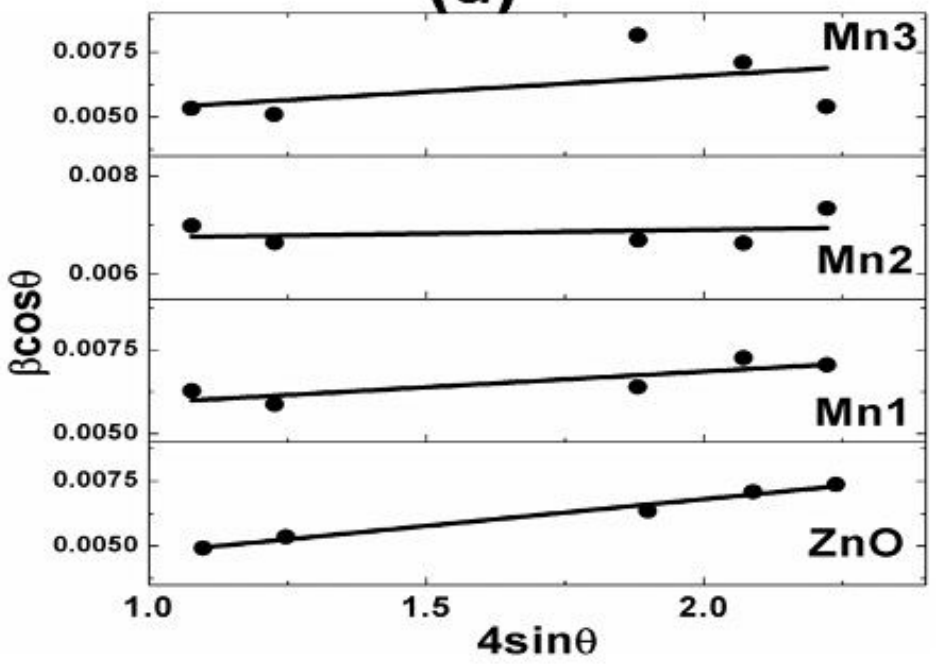

(b)

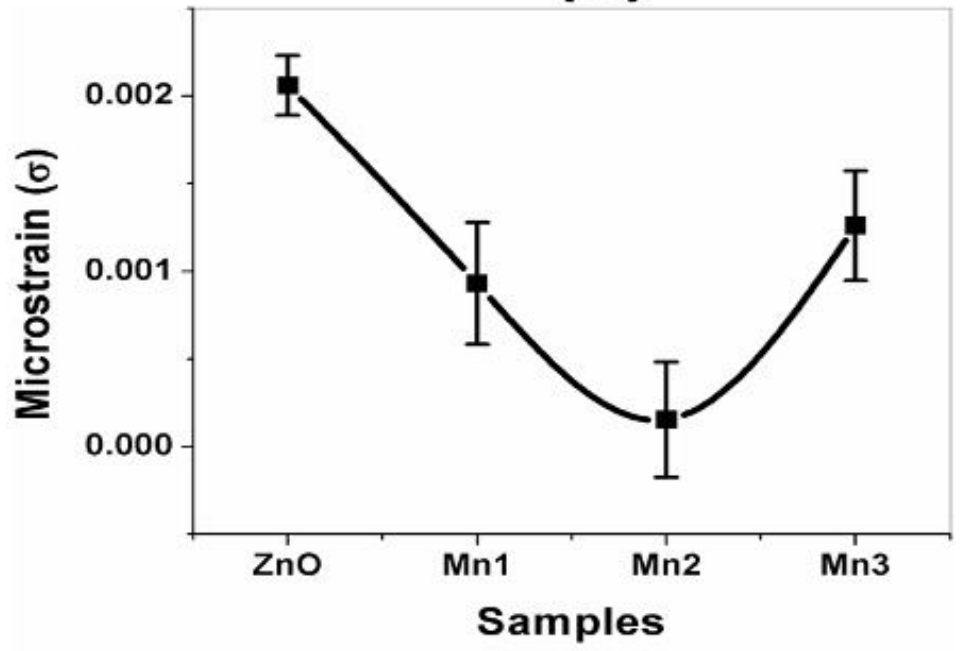

Figure 3

(a): The $\mathrm{W}-\mathrm{H}$ analysis of pure and $\mathrm{Mn}$ doped $\mathrm{ZnO}$ nanoparticles (b) Variation of microstrain along with the Mn concentrations 

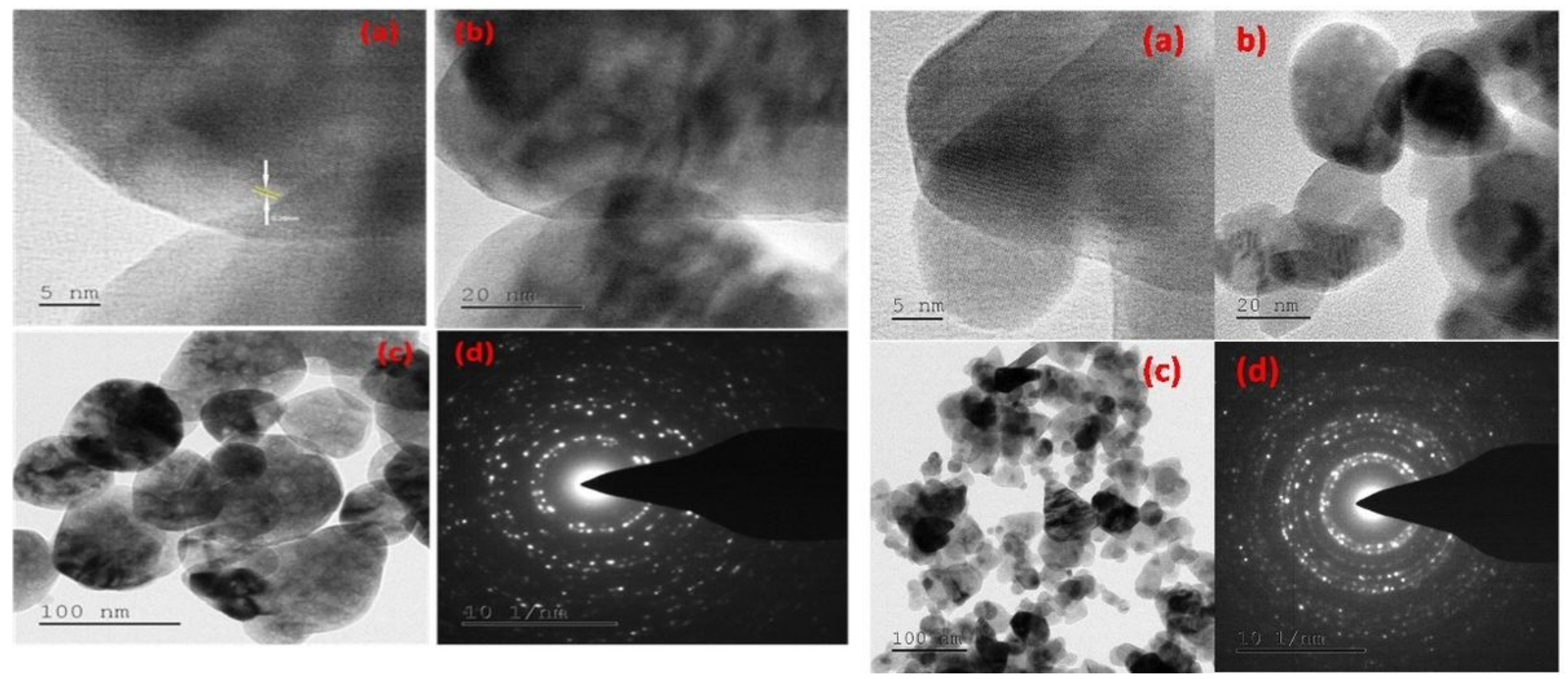

Figure 4

(a-d): HRTEM images and SAED pattern of Pure ZnO Nanoparticles. (a-d): HRTEM images and SAED pattern of $(\mathrm{ZnMnO2}) \mathrm{Mn}$ doped $\mathrm{ZnO}$ Nanoparticles 

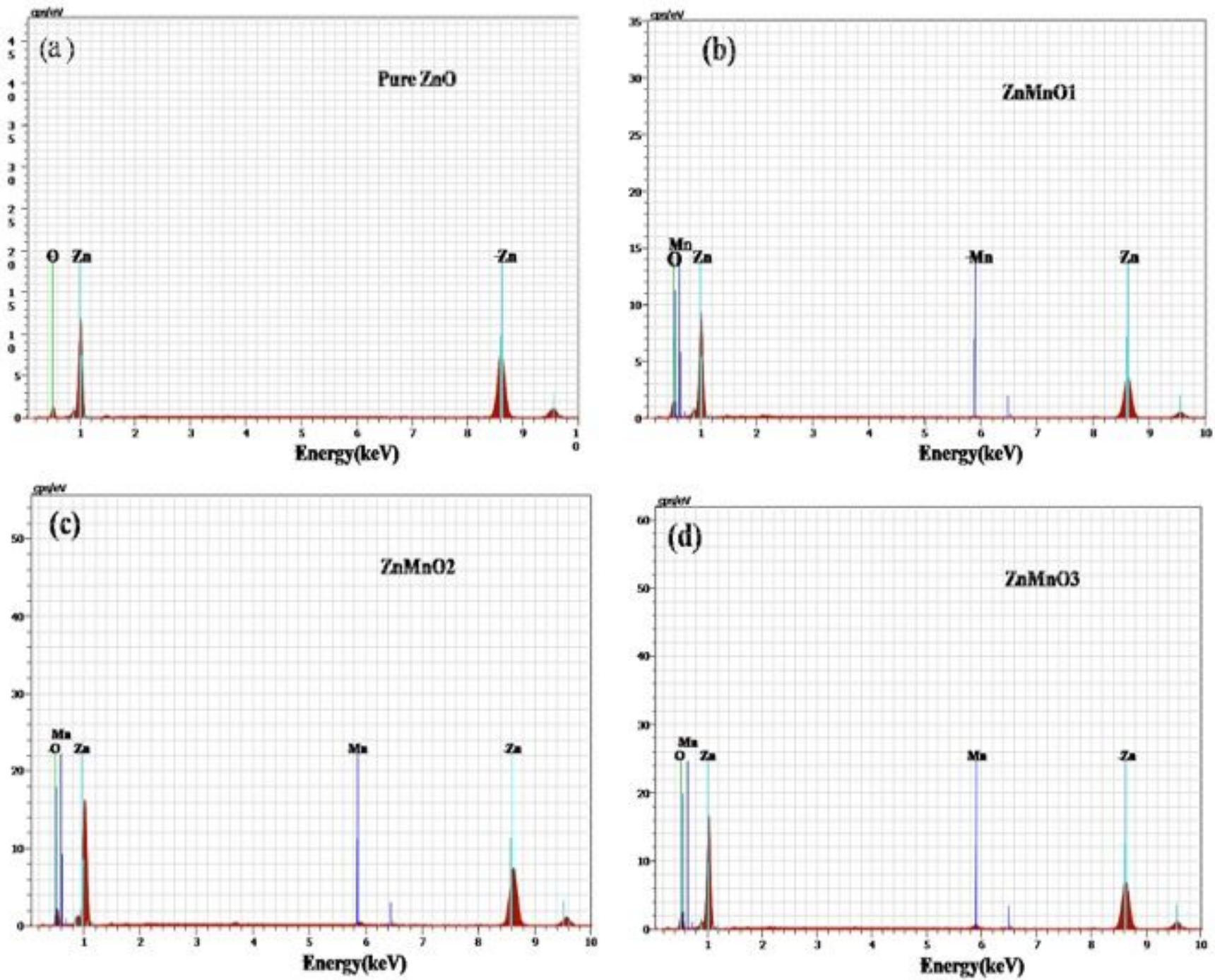

Figure 5

(a-d): EDAX spectrum for pure $\mathrm{ZnO}$ and different concentration of $\mathrm{Mn}$ doped $\mathrm{ZnO}$ nanoparticles. 


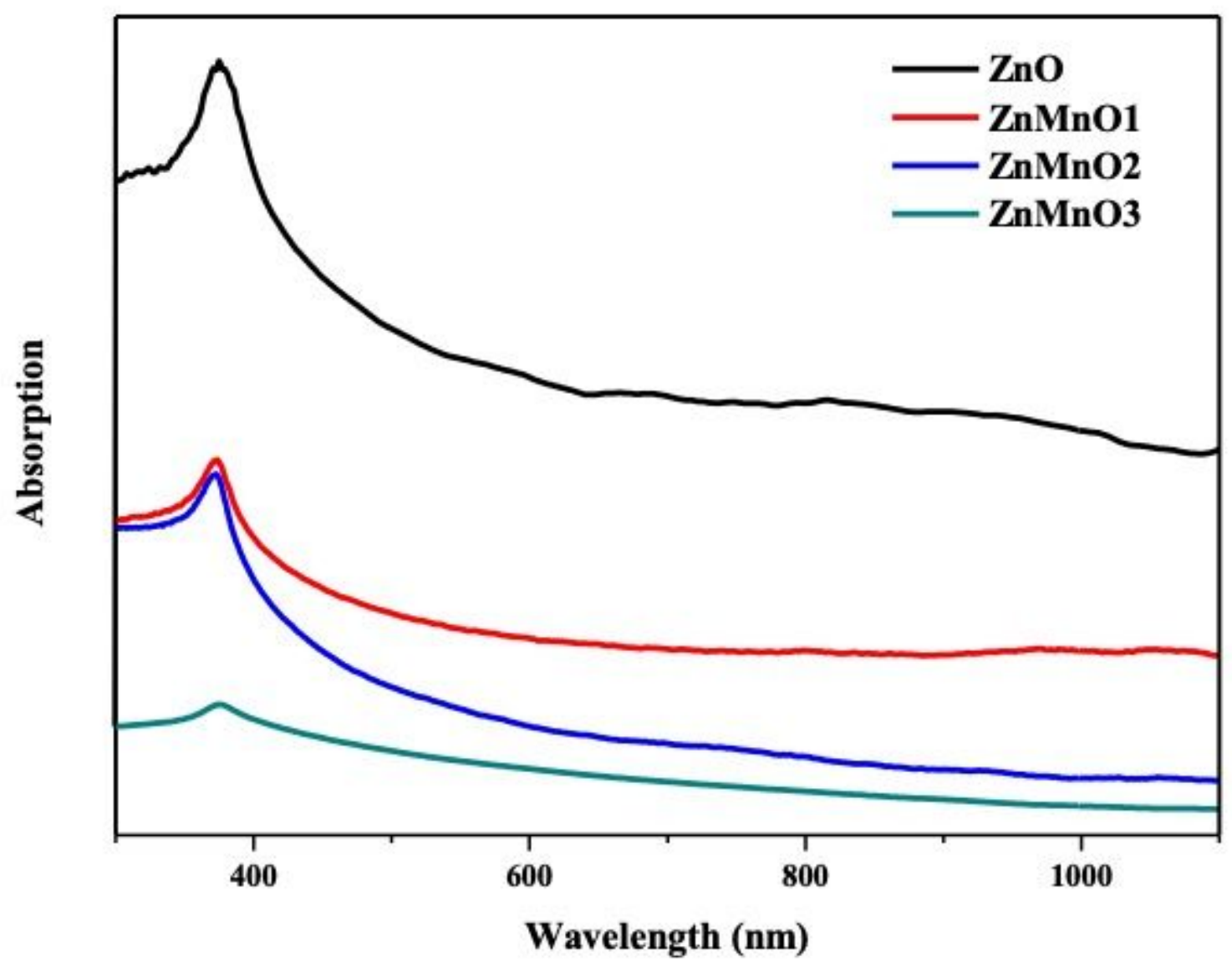

Figure 6

UV absorption spectra of pure $\mathrm{ZnO}$ and different $\mathrm{Mn}$ concentration of $\mathrm{ZnO}$ nanoparticles. 


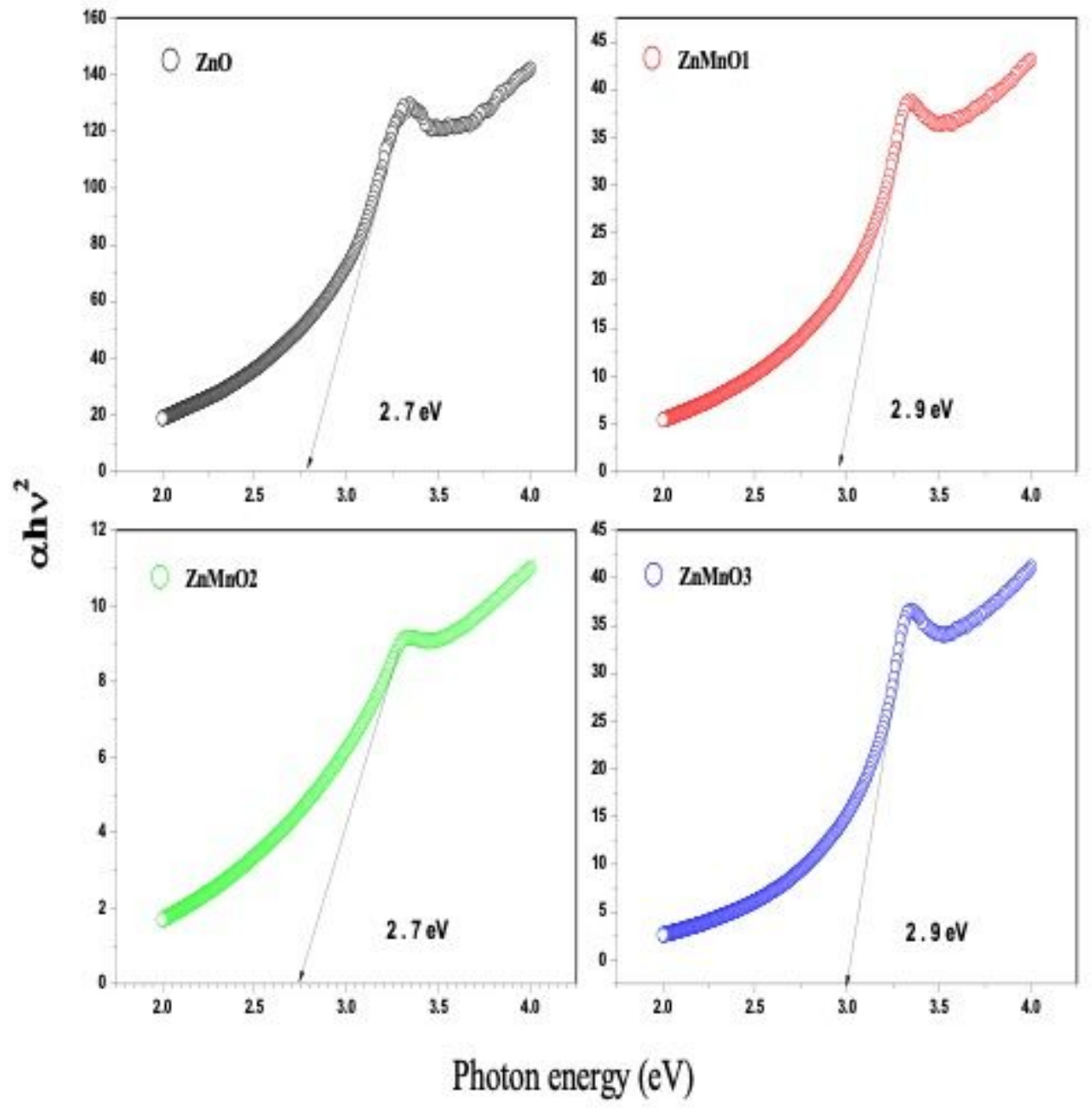

Figure 7

Shows band gap energy of $\mathrm{ZnO}$ and $\mathrm{Mn}$ doped $\mathrm{ZnO}$ Nanoparticles 
(a)

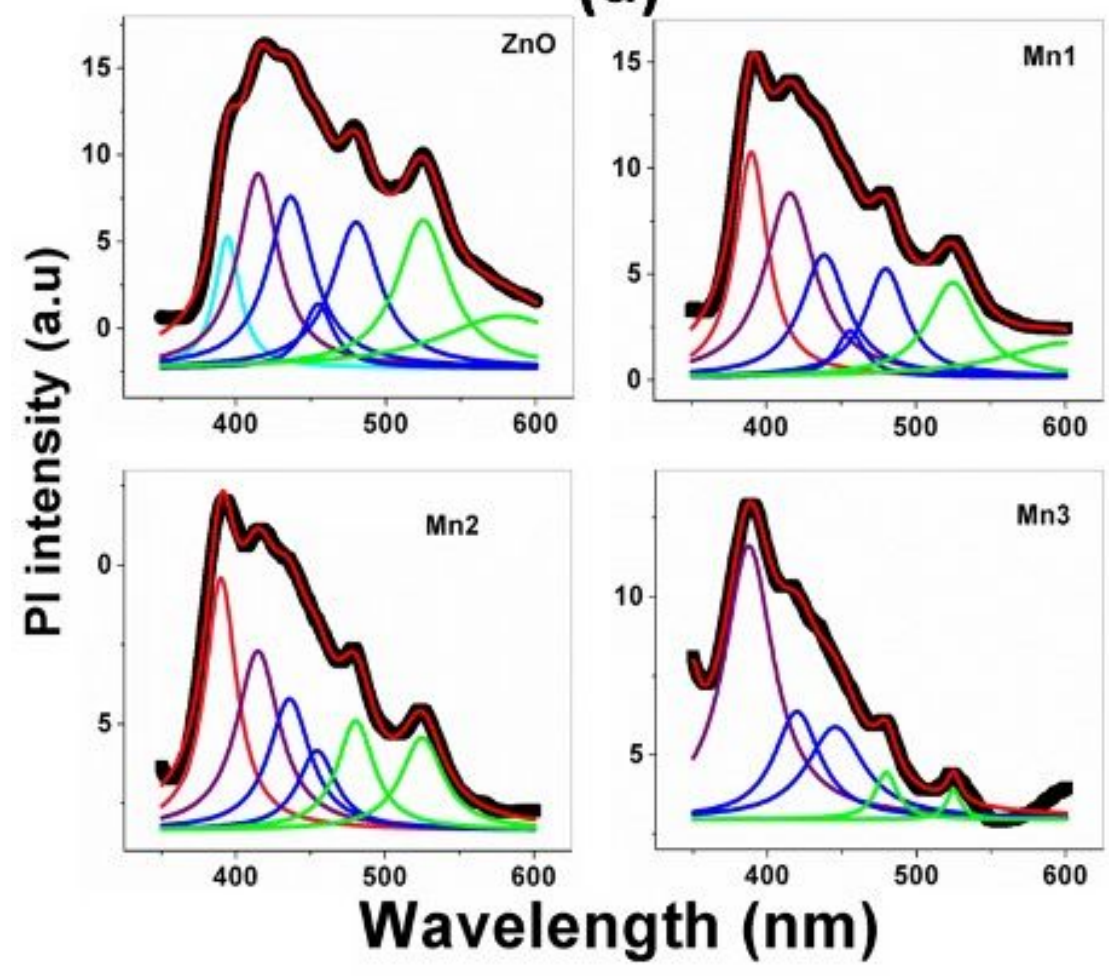

(b)

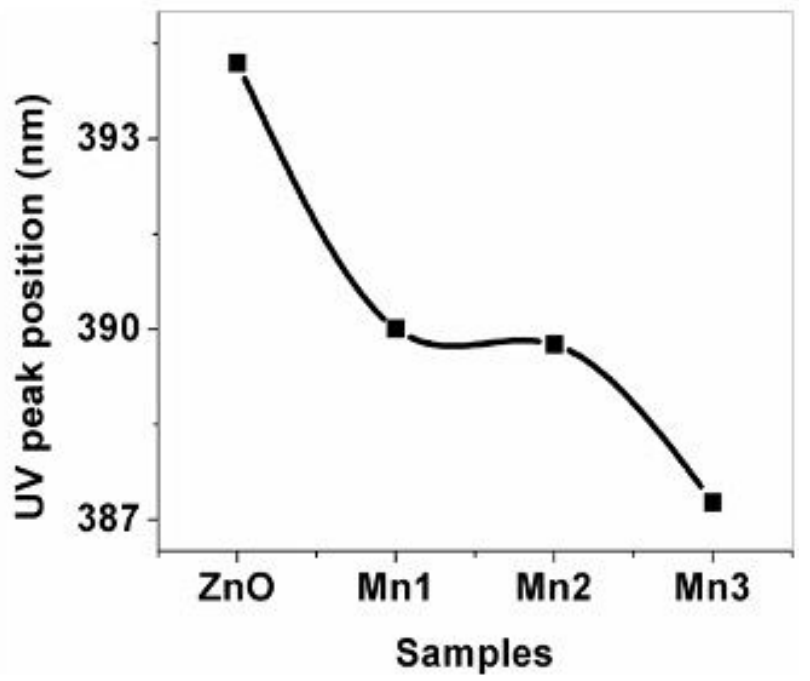

Figure 8

(a) Lorentzian decomposed photoluminescence spectra of $\mathrm{ZnO}$ and $\mathrm{Mn}$ doped $\mathrm{ZnO}$ nanoparticles and (b) variation in the UV peak position with respect to the Mn concentrations 


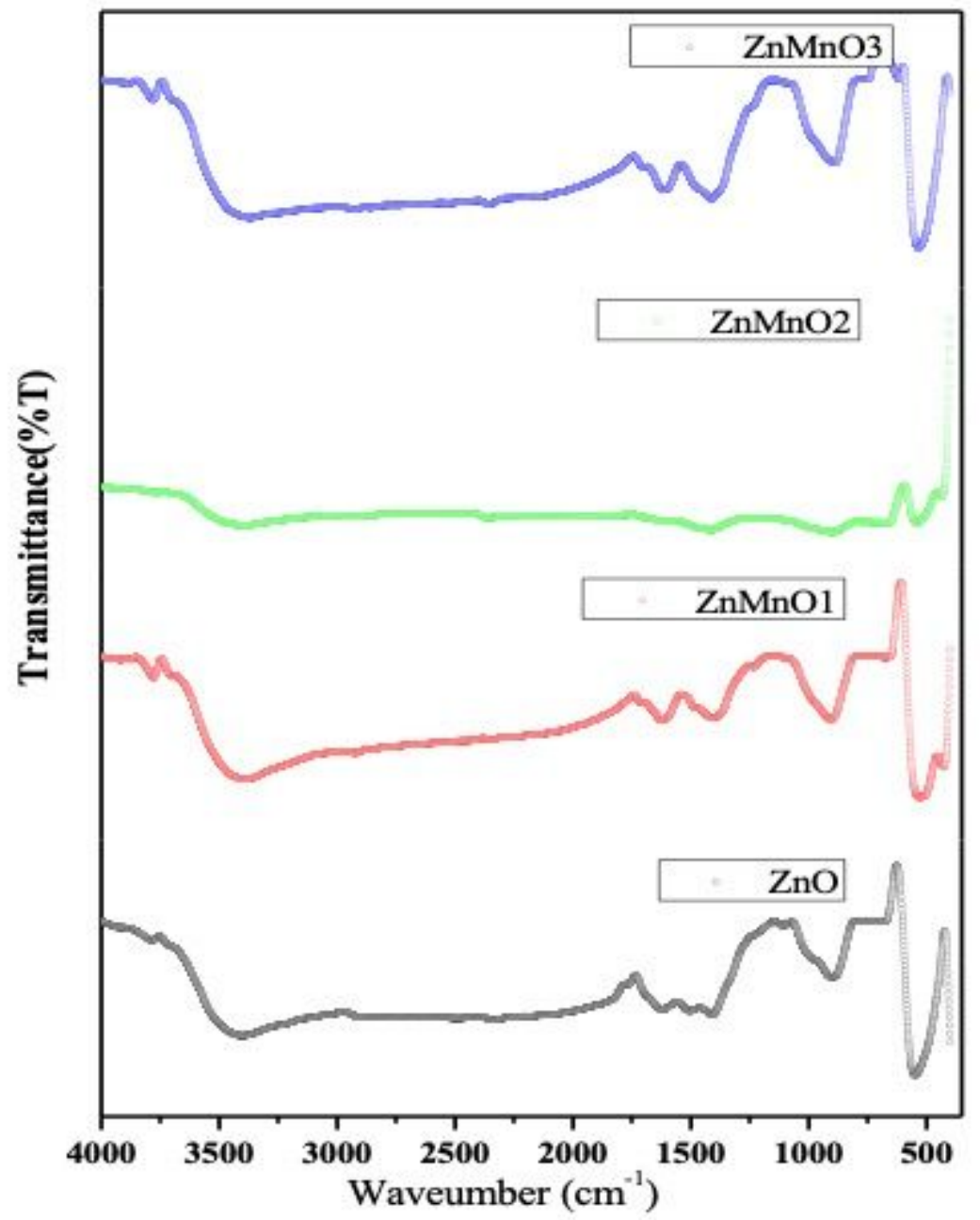

Figure 9

FTIR spectra of ZnO and $\mathrm{Mn}$ doped $\mathrm{ZnO}$ Nanoparticles
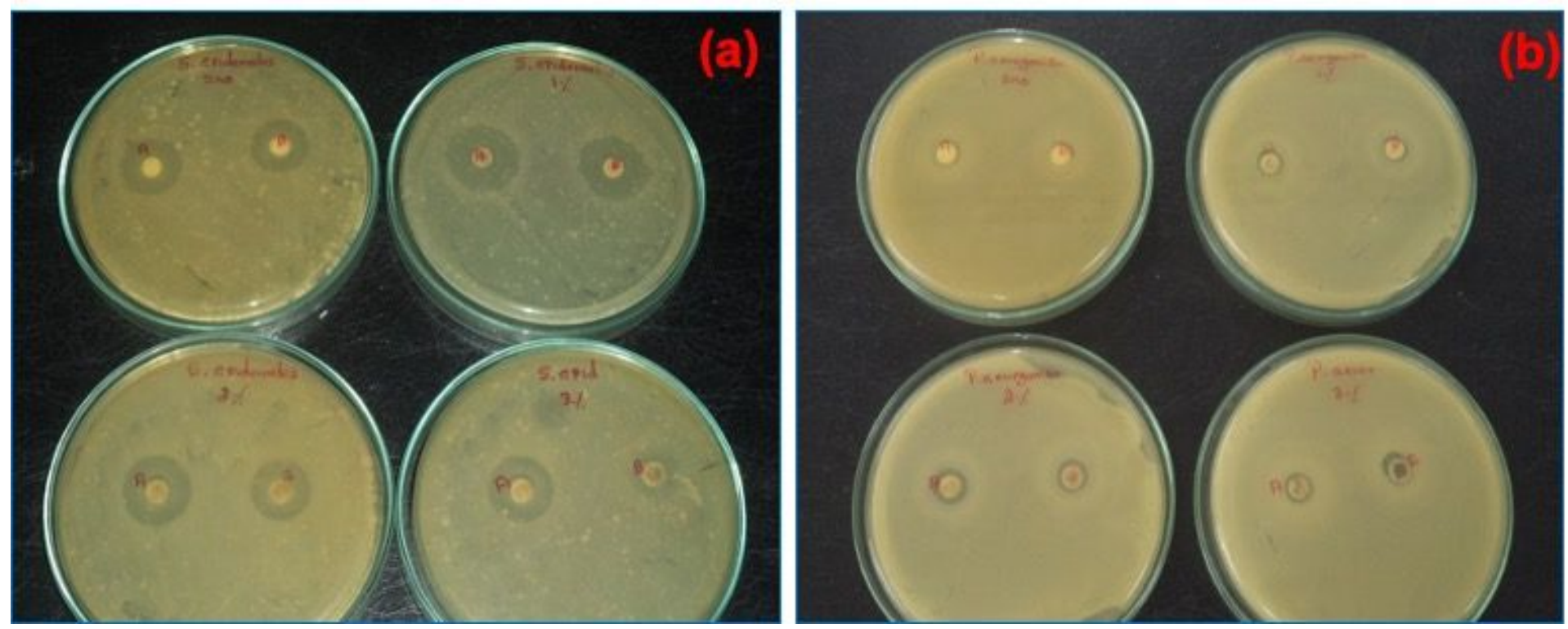
Figure 10

The zone of inhibition formed around each disc, loaded with test samples indicated the antimicrobial activity of (a) Staphylococcus epidermidis and (b) Pseudomonas aeruginosa.

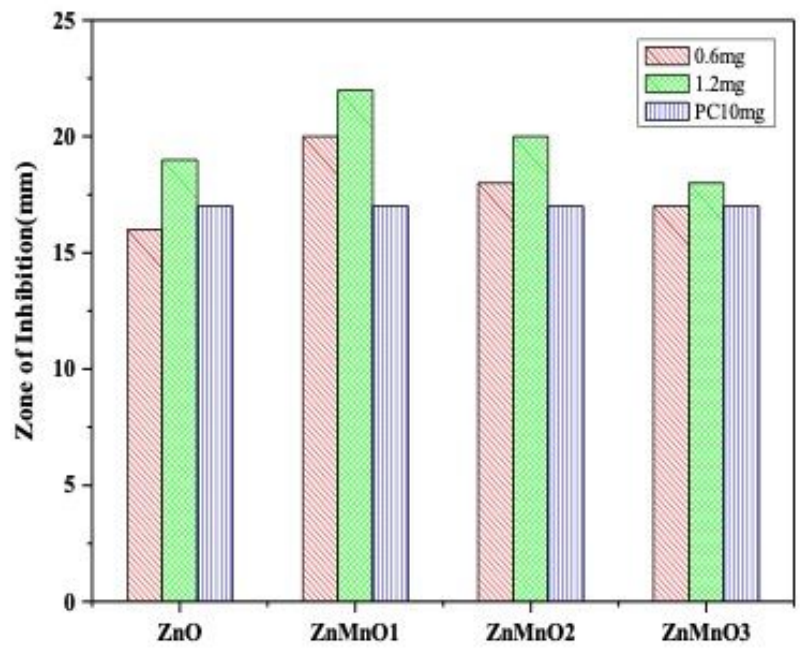

(a) S.Epidermis

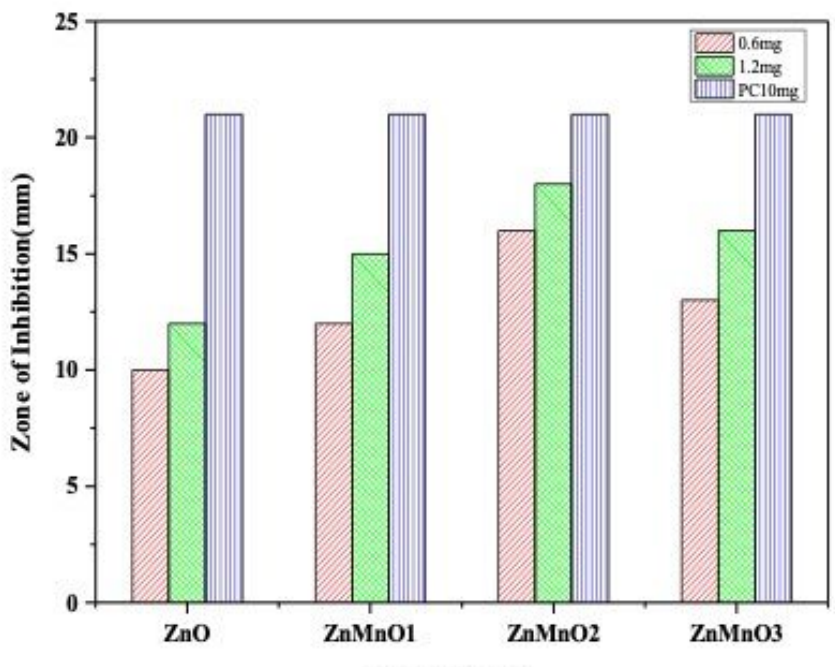

(b)P.aeruginosa

\section{Figure 11}

The zone of inhibition formed around each disc, loaded with test samples indicated the antibacterial activity of (a) S. Epidermis and (b) P. aeruginosa. 


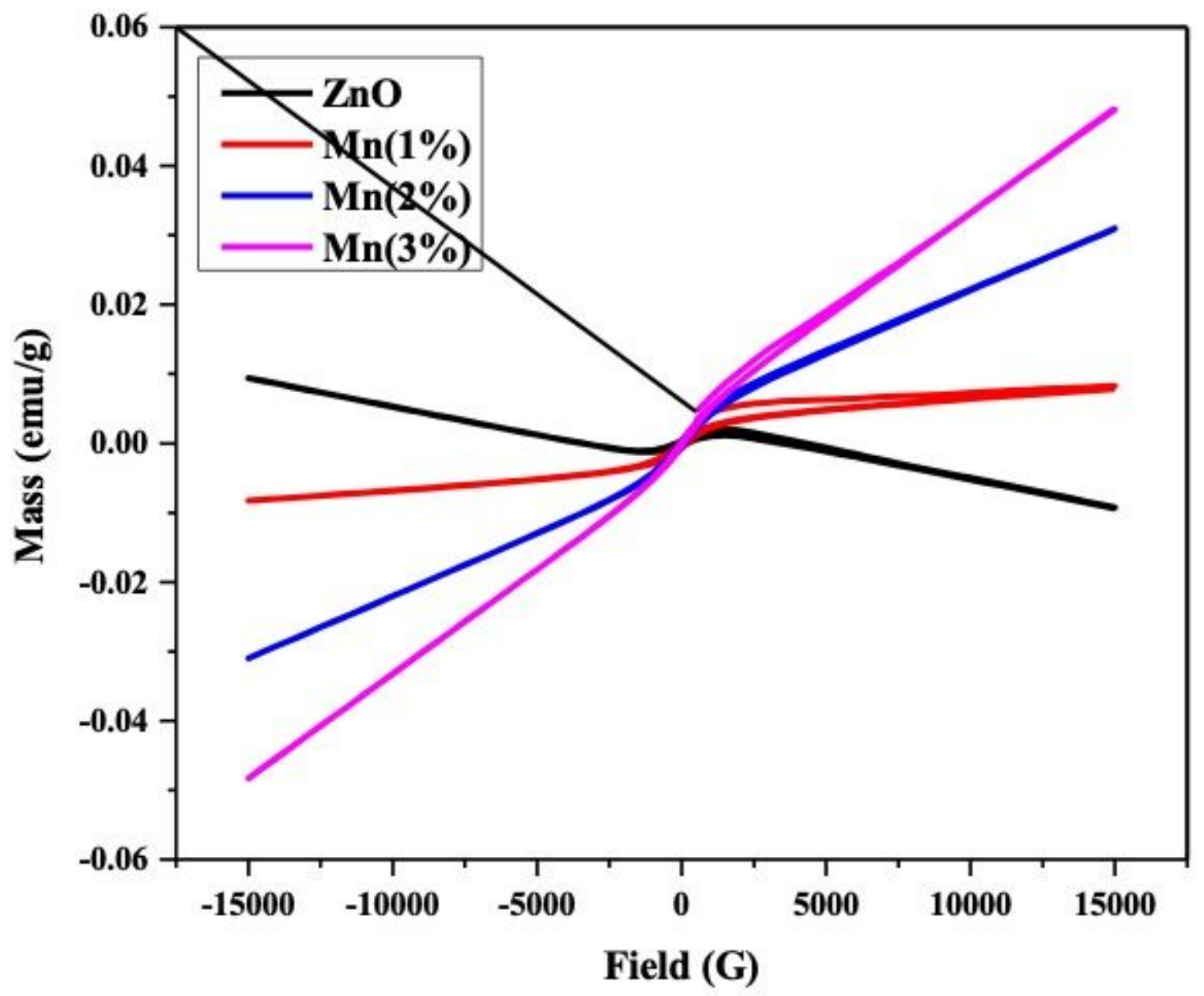

Figure 12

Magnetization curves loops for $\mathrm{ZnO}$ and $\mathrm{Mn}$ doped $\mathrm{ZnO}$ Nanoparticles 